Article

\title{
Key Factors Affecting Informed Consumers' Willingness to Pay for Green Housing: A Case Study of Jinan, China
}

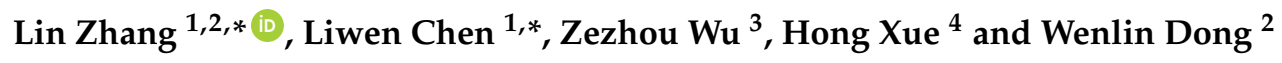 \\ 1 School of Economics and Management, Hebei University of Technology, Tianjin 300401, China \\ 2 School of Management Engineering, Shandong Jianzhu University, Jinan 250101, China; \\ dong.wenlin@yahoo.com \\ 3 Department of Construction Management and Real Estate, Shenzhen University, Shenzhen 518060, China; \\ wuzezhou@szu.edu.cn \\ 4 School of Management, Harbin Institute of Technology, Harbin 150001, China; xuehong@stu.hit.edu.cn \\ * Correspondence: zhanglin2007@sdjzu.edu.cn (L.Z.); Lwchen@hebut.edu.cn (L.C.); \\ Tel.: +86-0531-8636-1579 (L.Z.); +86-22-6043-5165 (L.C.)
}

Received: 7 May 2018; Accepted: 15 May 2018; Published: 24 May 2018

\begin{abstract}
In recent years, the issues of large energy consumption and degraded living environments have attracted considerable attention in developed and developing countries. Hence, green housing (GH) has become a popular strategy for achieving sustainable urbanization. The demand in the GH market played an important role in promoting GH. In China, whether potential consumers will pay for GH remains unclear. In this circumstance, this study aims to explore the willingness of construction practitioners, who are regarded to have more knowledge concerning $\mathrm{GH}$, to pay for $\mathrm{GH}$ in China. Based on the theory of planned behavior (TPB), nine critical factors related to practitioners' willingness to pay (WTP) were examined through face-to-face interviews using a questionnaire survey. A total of 180 construction participants in Jinan were investigated in this study. A binary logistic regression model was used to analyze the collected data. The research finding revealed that only 68 respondents were willing to pay for GH. Four factors showed significant and positive influences in practitioners' WTP, including environmental awareness, GH comfort, government incentive, and neighbors' / friends' assessment. By contrast, GH price displayed a significant and negative influence in practitioners' WTP. The remaining factors, namely, mature GH market, degree of popularity, publicity of GH from developers, and GH affordability, showed insignificant relationships with the practitioners' WTP. The research findings can provide a helpful reference for policy makers to formulate effective incentive policies in the promotion of GH.
\end{abstract}

Keywords: green housing; willingness to pay; theory of planned behavior; construction practitioners

\section{Introduction}

Given the rapid urbanization, the construction industry in China experienced a noticeable development in the past years. A total of 1.6-2.0 billion $\mathrm{m}^{2}$ buildings are constructed annually, and this number accounts for $40 \%$ of the world's new construction [1]. Green building (GB) is regarded as a measure to mitigate significant influences on the environment, society, and economy [2]. There are numerous benefits attained in the lifecycle of GB available in the built environment, such as cost saving, increased productivity, improved indoor air quality, and cost premium. Previous research has addressed the benefits, which includes a $10 \%$ property value premium [3], 7-8\% rental price premium [4], and an increase in employee productivity [5]. However, GB accounts for only $5 \%$ of new buildings in China [6], which remains considerably lower than conventional building [7]. With 
regard to the 13th five-year (2016-2020) plan to achieve more than 2 billion $\mathrm{m}^{2}$ of new GB and reach more than $50 \%$ of new buildings, the government will be confronted with notable challenges in upscaling green housing $(\mathrm{GH})$. Generally, GH promotion largely depends on the demands of potential consumers. Buyers' choice and willingness to pay (WTP) play an important role in GB development [8]. Qian et al. [9] found that real estate developers' uncertainty about the market and consumers is the highest concern for risk in GB development. Gu and Zhang [10] indicated that market demand is the most important factor that influences the GB decision making of developers. The developers will supply it to the market only when the purchasers are willing to pay the additional cost for GH [11].

Thus, buyers or tenants' WTP for GH have attracted research interests at home and abroad. Studies include office tenants [12] and university students [13] in the United States; residents in Hong Kong [11]; corporations in Switzerland; consumers of green apartments in Nanjing [14] and Sweden [15]; green residents in Beijing [16,17]; and in addition the research of Lanzhou [18], Jinan [19], and Macau [20] have also produced notable findings. In the developed countries, Chan et al. [21] explored the obstacles of GB promotion in Hong Kong and Singapore from the perspective of designers who play a relatively neutral role in the GB business. They found that the lack of awareness about GB is a main obstacle in both cities. Developing countries acted in the same way. In China, Zhang, Wu and Liu [8] showed that residents' knowledge about the greenness of a building is scarce. The problem of information asymmetry and adverse selection are more serious in the GB sector than ordinary buildings [22]. A shortage of information about GH can lead to consumer uncertainty about the benefits of GB and the hesitation to choose it. Most users had no to limited specialized knowledge or sufficient information to assess a building's energy efficiency [23]. In contrast construction practitioners are especially referred to as potential home buyers who participated in developing, planning, designing, surveying, supervising, constructing, consulting, managing property, and supplying materials and equipment for GBs and possessed considerable knowledge on the technology, advantages, and risks of GH. Nguyen et al. [24] conducted an exploratory study of barriers to GB in Vietnam by means of a questionnaire survey of construction stakeholders and found that most constructional professionals had a raised awareness of GB through conferences, workshops, and television programs. Generally, most of them are familiar with the benefits of GBs. Although green certification, including LEED and energy star in the US, GREEAM in the UK, green Mark in Singapore, and green building label in China can be a useful approach in solving information problems and assist consumers in making better choices, they are often too coarse for consumers to make efficient decisions [25]. At the presale stage of GH, they can attain more accurate and credible information about GBs and make a better decision. When they make a decision to purchase the $\mathrm{GH}$, the issue of information asymmetry in the GB market may be avoided.

This paper aims to investigate the key factors affecting specific consumers' WTP for GH for the following two reasons. The first one is that sociodemographic characteristics, which include age, income, occupation, income situation, and educational level [26] are also the influential factors identified from previous research. Grosskopf and Kibert [27] indicated that consumer ages, professional occupations, and annual incomes affect the WTP for several water and energy conservation measures. Another study used a conjoint model to evaluate the WTP for a green apartment by different socioeconomic groups in China and revealed that only rich and health-concerned people prefer to pay to improve their living comfort [14]. Attaran and Celik [13] investigated the students' environmental responsibility and their WTP for studying and living in GBs at New England University and found that female students are more environmentally responsible than male students. Robinson, Simons, Lee, and Kern [12] analyzed the demand for green office building features among office tenants in the United States and determined that public firms and firms in the energy and information technology industries are most likely to pay for green-labeled buildings. Construction practitioners with a potential GH purchasing intention are characteristic of informed consumers. To our knowledge, there is no research investigation into the WTP of construction practitioners for GH. This present research can enrich the scope of sociodemographic characteristic groups. The second reason is due to the demonstration role 
of construction practitioners. They are chosen as a specific segment of consumers who can serve as the pioneers of GH buyers. The findings of this research can contribute and reveal the key factors affecting an informed consumer's WTP for green housing. It can also offer valuable strategic recommendations for the government after the general consumers have gained sufficient knowledge about GH. Therefore, the current study can be provided as an effective measure for the government to adjust the regulation and economic incentive policies related to upscaling the next step of GB promotion.

The theory of planned behavior (TPB) was adopted because it was not only the most commonly applied psychology theory in explaining health and pro-environmental behavior [28], but was also one of the most commonly referenced theories in the field of green consumerism $[29,30]$. Furthermore, the findings from Chan and Lau [31] indicated the applicability and universality of TPB in different cultural settings; for instance, consumers' green purchasing behavior in Chinese and American cultural contexts. Thus, TPB was chosen as the theoretical basis to identify the key factors that affect construction practitioners' decisions with respect to purchasing GH in China.

Given that this study involves different terminologies, such as GH, conventional housing, WTP, and construction practitioners, a reference for these terminologies is provided in Table 1.

Table 1. Nomenclature table.

\begin{tabular}{ll}
\hline \multicolumn{1}{c}{ Terminology } & \multicolumn{1}{c}{ Definitions in This Paper } \\
\hline $\begin{array}{l}\text { Green housing (GH)/ } \\
\text { green building (GB) }\end{array}$ & $\begin{array}{l}\text { GB definition according to four pillars; i.e., minimization of influences on the } \\
\text { environment, enhancement of the health conditions of occupants, the return on } \\
\text { investment to developers and the local community, and the life cycle } \\
\text { consideration during the planning and development process [32] }\end{array}$ \\
\hline Conventional housing & Buildings as opposed to GB \\
\hline $\begin{array}{l}\text { Construction } \\
\text { practitioners }\end{array}$ & $\begin{array}{l}\text { Potential home buyers who participated in developing, planning, designing, } \\
\text { surveying, supervising, constructing, consulting, and supplying materials and } \\
\text { equipment for GB and who obtain considerable knowledge on the technology, } \\
\text { advantages, and risks of GH }\end{array}$ \\
\hline General consumers & Persons who intend to purchase a unit of housing for their own use \\
\hline Developer & Company that developed a conventional housing or GH \\
\hline
\end{tabular}

Additionally, China is a good laboratory for this research due to the following reasons. First, China possesses the largest construction market in the world [33]. Achieving sustainability in the Chinese construction industry will play a prominent role in reducing the adverse effects of climate change, the built environment, and human health worldwide. Second, China is a representative of the developing countries who suffer a similar conflict between economic development and environmental degradation. Thus, the present findings can provide useful experiences for policy makers and other institutions in other developing countries. Third, previous studies on the WTP for GH were mentioned previously in Nanjing [14] and Beijing [23], which are First-tier cities. To our knowledge, there was little research in the Second-tier cities, and therefore the findings can be extended to the mass cities in China. The present findings can serve as a valuable reference for the government in policy formulation to upscale GH. This study can also contribute to the body of knowledge in the area of GB research.

The following sections of this paper include a literature review of current studies, an explanation of the research methodology, a description of the results and discussion, and a conclusion.

\section{Literature Review}

\subsection{Theory of Planned Behavior (TPB)}

TPB, which was proposed by Ajzen in 1985, is one of the most widely used theories of behavior. TPB is also the most popular theory to examine individuals' intention and behavior [34]. In the TPB framework, behavioral intention is determined by the attitude toward behavior $(A B)$, subjective 
norm (SN), and perceived behavioral control (PBC) [35]. Correspondingly, the TPB framework is illustrated in Figure 1. In the theoretical framework, it can be seen that the behavioral intention or WTP for green housing is directly influenced by one's attitude, subjective norm, and perceived control. Generally, behavior is directly affected by behavioral intention. The more positive the individual attitude, the more support from relevant persons as well as the more perceived autonomic control, the higher behavioral intention of the person [33].

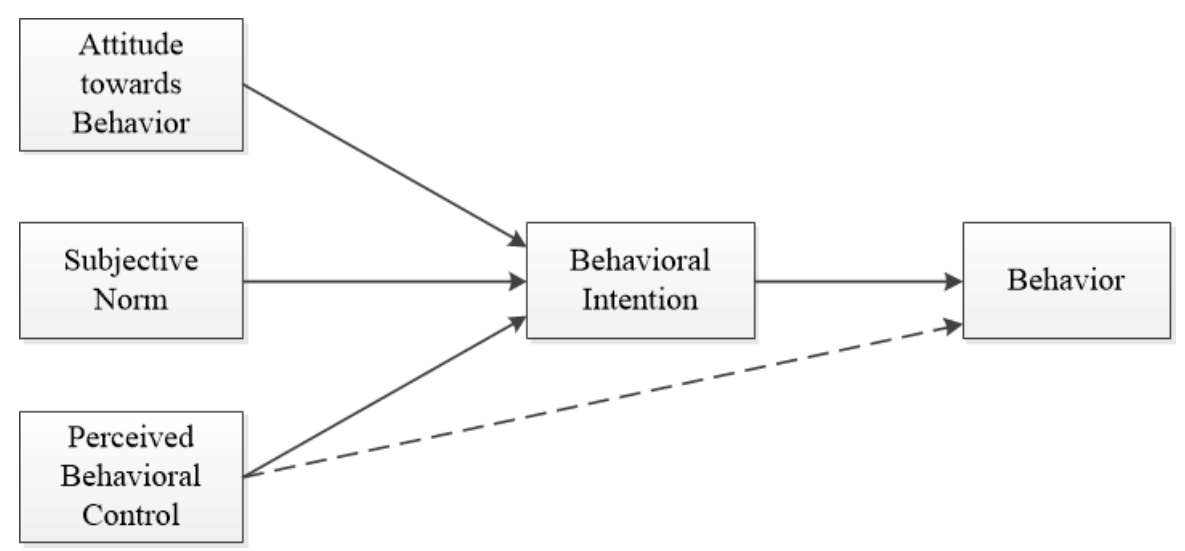

Figure 1. Framework of planned behavior theory.

To date, TPB has been applied to predict consumers' intention and behavior in a wide range of areas, including environmentally sustainable products [36], electric vehicles [37], green hotels [38,39], and energy conservations [40,41]. This theory is a powerful model in explaining environmentally friendly behavior [42]. Maichum, Parichatnon and Peng [34] investigated Thai consumers who were aged 18 years with high school or higher education in terms of their purchasing intention for green products. They indicated that $\mathrm{AB}, \mathrm{SN}$, and $\mathrm{PBC}$ exert significant positive influences on their purchase intention.

\subsection{Research Hypotheses}

In the TPB framework, $\mathrm{AB}, \mathrm{SN}$, and PBC are the three basic factors. Other factors are evaluated by a number of beliefs and criteria. In the case of the practitioners for $\mathrm{GH}$, the intention indicates the subjective probability of WTP for GH. Strong intention will result in high probability. In accordance with TPB and previous literature, this study considers these factors, with each factor composed of three subfactors indicated in the following sections.

\subsubsection{Practitioners' Attitude towards Behavior}

Attitudes are related to other psychological and cultural dimensions; e.g., beliefs, intentions, and behavior. Consumers with positive environmental attitudes and awareness present more WTP for the incremental cost for green products than those of other consumers [43]. Li et al. [44] identified factors influencing WTP for low-carbon products and found that attitude, price, and economic incentive are important factors. Chau et al. [45] further used discrete choice experiments to examine the attitudes of residents in Hong Kong toward the green attributes of a residential property; they reported that the respondents were willing to pay additional money for energy conservation.

$\mathrm{AB}$ is a positive or negative feeling that a person expresses on the behavior or an attitude that is formed by evaluating an individual's behavior. With a positive GH evaluation, practitioners will likely pay for such house. Practitioners' attitude is the general feelings toward GH, either favorable or unfavorable. In the real estate market, practitioners may prefer to pay for a conventional building or a green counterpart. Market price, operation cost, and living comfort are the main factors affecting consumers' decision to buy GB [17]. According to the practitioners' attitude toward GH, the following subfactors are considered: 
(1) Environmental concern. The strong environmental concern of a consumer can result in a high WTP for GH [46]. Serious environmental pollution and energy depletion are accompanied with rapid development in the construction industry in China. Thus, practitioners with considerable environmental concern will likely express more WTP for GH than those of other practitioners.

(2) GH price. The initial construction cost of GH is higher than that of the conventional one [47-49]. An increase of $10.77 \%$ in construction cost is incurred due to the incorporation of a new GB code for residential project development [50]; consequently, the WTP for GH will inevitably decrease. Each rational economic person tends to select the product with the low prices without any interference. Therefore, a high GH price will result in less WTP for GH.

(3) Comfort degree. With the advantages of a high degree of comfort and good living experiences, GH can significantly improve the quality of life [17,51]. If the practitioners intend to upgrade their living space, then they will likely pay for GH. Correspondingly, the following hypotheses are proposed:

Hypothesis 1 (H1). Environmental concern exerts a positive influence on the practitioners' WTP for GH.

Hypothesis 2 (H2). GH price displays a negative influence on the practitioners' WTP for GH.

Hypothesis 3 (H3). GH comfort presents a positive influence on the practitioners' WTP for GH.

\subsubsection{Practitioners' Subjective Norm}

$\mathrm{SN}$ is the perception of social pressure that a person feels toward a particular behavior. Individuals' behavior will be affected by the opinion of other people or groups who are important to them and be influenced in their decision making. In this research, SN particularly refers to signals from the government, practitioners' neighbors/friends, and the market. A positive or negative SN may significantly affect intention and behavior. In the context of the related literature, this study investigated the following subfactors: governmental incentive policies, neighbors/friends' opinions, and the maturity of the GH market.

(1) Governmental incentive policies. These policies include financial subsidies, tax deduction, exemptions, and other related policies, which are crucial in motivating consumers' WTP [52]. Notably, if economic subsidies from the government are available, then practitioners will show a notable WTP for GH.

(2) Neighbors' / friends' assessments. Given the traditional relational culture in China, the consumers' purchasing decision making, especially when buying large items (houses or cars), will consider opinions and suggestion from family members, friends, neighbors, and other social groups that they trust [53]. Thus, the neighbors' / friends' assessments are subfactors that should also be considered.

(3) Mature GH market. Robust green technologies and adequate maintenance should be available in the solar housing market [54]. The GH market acts in the same manner. The continuous expansion in the GH market will strengthen the practitioners' WTP for GH. Hence, the following hypotheses are proposed:

Hypothesis 4 (H4). Governmental incentive policies will exert a positive influence on the practitioners' WTP for $G H$.

Hypothesis $\mathbf{5}$ (H5). Neighbors'/friends' assessments will exert a positive influence on the practitioners' WTP for $\mathrm{GH}$.

Hypothesis 6 (H6). Mature GH market will exert a positive influence on the practitioners' WTP for GH. 


\subsubsection{Practitioners' Perceived Behavioral Control}

PBC refers to an individual's ability to control their behavior when performing a particular action. In this paper, $\mathrm{PBC}$ indicates practitioners' perception of the degree of $\mathrm{GH}$ popularity, GH publicity from developers, and GH affordability. Practitioners with more knowledge on GH, higher income, and wider opportunities to gain insight into GH will present stronger control beliefs and perceived power than those of other practitioners. Accordingly, this paper examines the following subfactors:

(1) Degree of GH popularity. High GH popularity will result in high probability of the consumers' purchasing behavior due to the bandwagon effect in China [53]. Similarly, the high degree of popularity exerts a significant influence on consumers' attitude toward environment-friendly behavior [29].

(2) GH publicity from developers. Available, accessible, and credible publicity information on GB is important for end users to ensure a guaranteed performance in terms of operation and maintenance [55]. Developers will map out the strategy to publicize their products in the marketing stage. With their profit-oriented nature, they commonly aim to achieve a high economic return in a short time. If they intend to develop GH, then they must create novelty and distinctness to attract individuals' attention during product publicity. To improve the popularity of $\mathrm{GH}$, many consumers are informed of its location and feature, as well as the development strength and capacity of developers. Consequently, potential practitioners may decide to buy GH. Therefore, the considerable publicity of GH from developers will result in high probability of the WTP for GH.

(3) GH affordability. Prior studies [14] reported that only rich consumers are prepared to pay for green apartments. If the construction practitioners can freely control their purchasing activities without pressure from financial expenses, then they can show strong affordability of GH. Thus, the considerable affordability of GH will result in the high probability of the WTP for GH. Correspondingly, the following hypotheses are proposed:

Hypothesis 7 (H7). The degree of GH popularity exerts a positive influence on the practitioners' WTP for GH.

Hypothesis 8 (H8). The GH publicity from developers exerts a positive influence on the practitioners' WTP for $G H$.

Hypothesis 9 (H9). The GH affordability exerts a positive influence on the practitioners' WTP for GH.

From the abovementioned factors, each factor consists three subfactors.as shown in Table 2.

Table 2. Subfactors obtained from previous literature.

\begin{tabular}{ccc}
\hline Factors & Subfactors & References \\
\hline \multirow{3}{*}{ Attitude toward behavior } & Environmental concern & {$[46]$} \\
& GH price & {$[47-49]$} \\
Subjective norm & GH comfort & {$[17,51]$} \\
& Governmental incentive policies & {$[52]$} \\
& Neighbors' / friends' assessments & {$[53]$} \\
& Mature GH market & {$[54]$} \\
Perceived behavioral control & Degree of GH popularity & {$[29,53]$} \\
& GH publicity from developers & {$[56]$} \\
& GH affordability & {$[14]$} \\
\hline
\end{tabular}




\section{Research Methodology}

\subsection{Interviews with Consumers}

Before the questionnaire survey, semi-structured interviews were conducted to compare cognition items of GH between construction practitioners and general consumers. A focus group meeting about GH was held with 22 construction practitioners, who were randomly selected from two real estate companies, two design companies consisting of two construction companies, one consulting company, one surveying company, one GB material supplier, and one GB equipment supplier. Table 3 shows the profile of the interviewees. According to the discussion findings, most of the participants expressed their positive prospects of $\mathrm{GH}$ and their further understanding of $\mathrm{GH}$ in terms of cost, real benefits, risks, and deficiency. Moreover, 30 general home-buyer consumers employed in the fields of medicine, e-business, computer, and mining engineering were interviewed by telephone conversation to investigate their subjective knowledge of GH.

Table 3. Profile of the interviewees.

\begin{tabular}{cccc}
\hline $\mathbf{N}$ & Occupation & Company & Number \\
\hline 1 & Real estate company & $\begin{array}{c}\text { Vanke real estate company } \\
\text { Landsea real estate company }\end{array}$ & 2 \\
\hline 2 & Design company & $\begin{array}{c}\text { Tong Yuan Design Company } \\
\text { Hanhua design company }\end{array}$ & 2 \\
\hline 3 & Construction company & $\begin{array}{c}\text { The Second Construction limited company of } \\
\text { China Construction Eighth Engineering Division }\end{array}$ & 2 \\
& & Tianqi construction company & 2 \\
\hline 4 & Consulting company & Lurong consulting company & 2 \\
\hline 5 & Surveying company & Longda quantity surveying company & 2 \\
\hline 7 & Property company & Jinke property company & 2 \\
\hline 8 & GB equipment supplier & Fangya ground source heat pump company & 2 \\
\hline
\end{tabular}

Table 4 presents a comparison of the cognition items of GH between construction practitioners and general consumers. General consumers presented minimal knowledge about GH. With consideration that consumers possess greater knowledge of the GH features, how the government takes action to motivate them to pay for GH should be determined. Therefore, the present research considered construction practitioners to be the segmented consumers in order to explore the WTP for GH in this context.

Table 4. Cognition items of GH between construction practitioners and general consumers.

\begin{tabular}{ccccc}
\hline \multirow{2}{*}{ Items } & Construction Practitioners & \multicolumn{2}{c}{ General Consumers } \\
\cline { 2 - 4 } & Frequency & Percentage & Frequency & Percentage \\
\hline Knowledge about the GH definition & 20 & $90.9 \%$ & 6 & $20 \%$ \\
Knowledge about the evaluation system of GH & 18 & $81.8 \%$ & 4 & $13.3 \%$ \\
Knowledge about economic benefits & 16 & $72.7 \%$ & 7 & $23.3 \%$ \\
Knowledge about environmental benefits & 21 & $95.5 \%$ & 12 & $40 \%$ \\
Knowledge about social benefits & 10 & $45.5 \%$ & 4 & $13.3 \%$ \\
Knowledge about cost premium & 13 & $59.1 \%$ & 5 & $16.7 \%$ \\
Knowledge about government policies on GH & 14 & $63.6 \%$ & 4 & $13.3 \%$ \\
\hline
\end{tabular}




\subsection{Questionnaire Survey}

A questionnaire survey was adopted for data collection. A pilot study was preliminarily conducted to evaluate the content validity. A total of $12 \mathrm{draft}$ questionnaires were distributed to 12 experts. The draft questionnaire was further modified on the basis of the experts' opinions and recommendations. Afterward, the formal survey was carried out in Jinan, which is the capital of Shandong Province in East China.

The questions in the formal questionnaire consist of three parts. The first part investigates the demographic characteristics of respondents, such as age, gender, education, annual family income, and occupation. The second part measures the affecting factors using a five-point Likert scale. The respondents can answer their WTP for GH in the third part.

A combination of convenience sampling and evaluation sampling was used for data collection. Two channels were selected for data collection. The first channel was questionnaire distribution in an expo. This event, which was called the "Intelligent, Green and Energy-Efficient Building \& New Technologies and Products Expo," was held on 27 October 2016 in Jinan, with the aim of promoting environment-friendly development in urban and rural construction fields. The participants in the expo included governmental officials, designers, contractors, green product suppliers, and energy performance contracting companies. During the expo, a total of 200 questionnaires were sent out by nine junior students to potential home buyers. Finally, 143 responses were received, and this number represented a valid response rate of $71.5 \%$. The other channel was a questionnaire distribution to adult education students in Shandong Jianzhu University. All of the students indicated at least three-years of working experience in construction practices. A total of 57 questionnaires were collected from this channel.

A total of 200 responses were collected from the two channels. Twenty responses were eliminated due to incomplete responses or conflict in reverse responses. The responses were filtered, and 180 responses, which represented $70.8 \%$ of the total responses, were used for further analysis. Cronbach's alpha was used to assess the internal consistency of the questionnaire. The Cronbach's alpha was 0.81 , which suggested that the internal consistency of the questionnaire is acceptable.

\subsection{Model Structure}

To accomplish the objective of this study, the items on $\mathrm{AB}, \mathrm{SN}$, and $\mathrm{PBC}$ were adopted from the existing relevant literature. The measurement was properly modified on the basis of the realistic situation of the GH market in China. WTP was the explained variable, with either a "yes" or "no" answer gathered from each participant. A binary logistic model was applied because only two levels were available. Nine independent variables corresponded to nine hypotheses, as illustrated in Table 4 . The probability of a "yes" answer was p, which is expressed in Equation (1):

$$
\mathrm{p}=1 /\left\{1+\exp \left[-\left(B+B_{1} X_{1}+B_{2} X_{2}+\ldots B_{9} X_{9}\right)\right]\right\}
$$

where $B$ is the regression constant term, and $B j$ is the regression coefficient for $X j$, which is an independent variable with $j=1,2 \ldots, 9$. Table 1 presents the explained and independent variables. The WTP was measured with nine independent variables by using five-point Likert-type scales.

\subsection{Measurement Instrument}

According to the classical TPB, $\mathrm{AB}, \mathrm{SN}$, and $\mathrm{PBC}$ can be validly measured. After reasonable modification, the measures became highly suitable for research in China. Table 2 shows nine independent variables, each using a five-point Likert scale. The mean and standard deviation values are presented in Table 5. 
Table 5. Mean and standard deviation.

\begin{tabular}{|c|c|c|c|c|}
\hline Description & $\begin{array}{l}\text { Variables/ } \\
\text { Hypothesis }\end{array}$ & Meaning and Evaluation & Mean & $\begin{array}{r}\text { Standard } \\
\text { Deviation }\end{array}$ \\
\hline $\begin{array}{l}\text { Environmental concern } \\
\text { exerts a positive influence } \\
\text { on WTP }\end{array}$ & $\mathrm{X} 1 / \mathrm{H} 1$ & $\begin{array}{c}\text { Environmental concern exerts a positive influence } \\
\text { on WTP. Strongly disagree }=1 \text {, Slightly disagree }=2, \\
\text { Agree }=3 \text {, Slightly agree }=4 \text {, Strongly agree }=5\end{array}$ & 3.23 & 1.320 \\
\hline $\begin{array}{l}\text { GH price exerts a negative } \\
\text { influence on WTP }\end{array}$ & $\mathrm{X} 2 / \mathrm{H} 2$ & $\begin{array}{c}\text { GH price exerts a negative influence on WTP. } \\
\text { Strongly disagree }=1 \text {, Slightly disagree }=2, \\
\text { Agree }=3 \text {, Slightly agree }=4, \text { Strongly agree }=5\end{array}$ & 2.54 & 1.110 \\
\hline $\begin{array}{l}\text { GH comfort exerts a } \\
\text { positive influence on WTP }\end{array}$ & $\mathrm{X} 3 / \mathrm{H} 3$ & $\begin{array}{l}\text { GH comfort exerts a positive influence on WTP. } \\
\text { Strongly disagree }=1, \text { Slightly disagree }=2, \\
\text { Agree }=3, \text { Slightly agree }=4, \text { Strongly agree }=5\end{array}$ & 3.32 & 1.066 \\
\hline $\begin{array}{l}\text { Governmental incentive } \\
\text { policies will exert a } \\
\text { positive influence on WTP }\end{array}$ & $\mathrm{X} 4 / \mathrm{H} 4$ & $\begin{array}{c}\text { Governmental incentive policies will exert a } \\
\text { positive influence on WTP. Strongly disagree }=1, \\
\text { Slightly disagree }=2 \text {, Agree }=3 \text {, Slightly agree }=4, \\
\text { Strongly agree }=5\end{array}$ & 2.95 & 1.064 \\
\hline $\begin{array}{l}\text { Neighbors' / friends' } \\
\text { assessment will exert a } \\
\text { positive influence on WTP }\end{array}$ & $\mathrm{X} 5 / \mathrm{H} 5$ & $\begin{array}{l}\text { When purchasing a GH, neighbors' } / \text { friends }^{\prime} \\
\text { assessment will exert a positive influence on WTP. } \\
\text { Strongly disagree }=1 \text {, Slightly disagree }=2, \\
\text { Agree }=3 \text {, Slightly agree }=4 \text {, Strongly agree }=5\end{array}$ & 2.99 & 1.101 \\
\hline $\begin{array}{l}\text { Mature GH market will } \\
\text { exert a positive influence } \\
\text { on WTP }\end{array}$ & $\mathrm{X} 6 / \mathrm{H} 6$ & $\begin{array}{l}\text { Mature GH market will exert a positive influence on } \\
\text { WTP. Strongly disagree }=1, \text { Slightly disagree }=2, \\
\text { Agree }=3 \text {, Slightly agree }=4 \text {, Strongly agree }=5\end{array}$ & 3.49 & 1.054 \\
\hline $\begin{array}{l}\text { Degree of GH popularity } \\
\text { exerts a positive influence } \\
\text { on WTP }\end{array}$ & $\mathrm{X} 7 / \mathrm{H} 7$ & $\begin{array}{c}\text { The degree of GH popularity exerts a positive } \\
\text { influence on WTP. Strongly disagree }=1, \\
\text { Slightly disagree }=2 \text {, Agree }=3 \text {, Slightly agree }=4, \\
\text { Strongly agree }=5\end{array}$ & 3.53 & .971 \\
\hline $\begin{array}{c}\text { GH publicity from } \\
\text { developers exerts a } \\
\text { positive influence on WTP }\end{array}$ & $\mathrm{X} 8 / \mathrm{H} 8$ & $\begin{array}{c}\text { The GH publicity from developers exerts a positive } \\
\text { influence on WTP. Strongly disagree }=1, \\
\text { Slightly disagree }=2 \text {, Agree }=3 \text {, Slightly agree }=4, \\
\text { Strongly agree }=5\end{array}$ & 3.32 & 1.060 \\
\hline $\begin{array}{l}\text { GH affordability exerts a } \\
\text { positive influence on WTP }\end{array}$ & X9/H9 & $\begin{array}{c}\text { GH affordability exerts a positive influence on WTP. } \\
\text { Strongly disagree }=1, \text { Slightly disagree }=2, \\
\text { Agree }=3, \text { Slightly agree }=4, \text { Strongly agree }=5\end{array}$ & 2.97 & 1.059 \\
\hline
\end{tabular}

\section{Results and Discussions}

\subsection{Descriptive Analysis}

Among the 180 responses, 68 expressed the WTP for GH, which indicated the construction practitioners' low WTP for GH in China. Table 6 presents the demographic characteristics of the respondents. Female respondents were less than those of male respondents. Respondents were mainly at the age of 31-40 (38.3\%) and 26-30 (30\%) and with a bachelor's degree (63.9\%). Half of the respondents $(50.6 \%)$ were professionals in the construction industry. Furthermore, $51.7 \%$ of the respondents' annual income was 50,001-100,000.

Table 6. Demographic characteristics of respondents.

\begin{tabular}{cccc}
\hline Type & Selection & Frequency & Percentage \\
\hline \multirow{2}{*}{ Gender } & Male & 112 & 62.2 \\
& Female & 68 & 37.8 \\
& 25 and younger & 25 & 13.9 \\
\multirow{2}{*}{ Age } & $26-30$ & 54 & 30 \\
& $31-40$ & 69 & 38.3 \\
& $41-50$ & 24 & 13.3 \\
& $51-60$ & 7 & 3.9 \\
& 61 and older & 1 & 0.6 \\
\hline
\end{tabular}


Table 6. Cont.

\begin{tabular}{cccc}
\hline Type & Selection & Frequency & Percentage \\
\hline \multirow{2}{*}{ Marital status } & Married & 107 & 59.4 \\
& Unmarried & 73 & 40.6 \\
Having children & 0 & 39 & 21.7 \\
& 1 & 123 & 68.3 \\
& 2 and more & 18 & 10 \\
Occupations & Professional in construction industry & 91 & 50.6 \\
& Government official & 33 & 18.3 \\
& GB material supplier & 35 & 19.5 \\
Education level & GB equipment supplier & 15 & 8.3 \\
& Other & 6 & 3.3 \\
& Junior college and lower & 34 & 18.9 \\
Annual income & College/university & 115 & 63.9 \\
(Chinese Yuan) & Master's and higher & 31 & 17.2 \\
& 50,000 and less & 31 & 17.2 \\
& $50,001-100,000$ & 93 & 51.7 \\
& $100,001-150,000$ & 28 & 15.6 \\
& $150,001-200,000$ & 20 & 11.1 \\
& 200,001 and more & 8 & 4.4 \\
\hline
\end{tabular}

\subsection{Hypothesis Testing and Discussion}

Data obtained from the questionnaire survey indicated that different variables exerted positive, negative, or no influence on the WTP for GH. Nine hypotheses were tested by using SPSS 21.0 soft package. Table 3 demonstrates that the Cox and Snell R Square and Nagelkerke R Square values were 0.249 and 0.339 , respectively. These values indicated the closeness between the model and the data, as well as the relationship between the explained and independent variables, as presented in Table 7. The Nagelkerke R Square was 0.339 , which can infer that the model can interpret the practitioners' WTP for GH. The log likelihood value was 187.052, thereby reaching the significance level. Thus, the goodness-of-fit was satisfactory. Nonetheless, the sig value was less than 0.05 in the Hosmer-Lemeshow test, as illustrated in Table 8. The value failed to reach the significance level.

Table 7. Test of the whole model.

\begin{tabular}{cccc}
\hline Step & Log Likelihood & Cox and Snell R Square & Nagelkerke R Square \\
\hline 1 & 187.052 & 0.249 & 0.339 \\
\hline
\end{tabular}

Table 8. Hosmer-Lemeshow test.

\begin{tabular}{cccc}
\hline Step & Chi-Square & df & Sig \\
\hline 3 & 51.616 & 9 & 0.001 \\
\hline
\end{tabular}

\subsubsection{Practitioners' Attitude towards Behavior}

According to the values listed in Table 9, five factors exerted significant influences on WTP, with "sig" values equal to or less than 0.05 . H1 was supported, with B1 $=0.463$ and EXP (B1) $>1$. The results indicated that the environmental concern of practitioners was the third strongest factor to influence the WTP for GH. The result that only the practitioners with stronger environmental concern can likely lead to more WTP for GH compared with those of other practitioners is relatively normal. Moreover, previous studies in other areas confirmed this result [38,44,57].

$\mathrm{H} 2$ was also supported, with $\mathrm{B} 2=-0.558$ and EXP $(\mathrm{B} 2)<1$. On the basis of the findings, $\mathrm{GH}$ price was identified as the second strongest factor to influence the WTP for GH. In comparison with the lower cost associated with a traditional house, the additional cost incurred in GH will result 
in a high price. Reducing the GH cost by means of environment-friendly technology innovation, renewable energy use, optimization design, green construction method integration, and facilities management in the whole chain of the construction industry is crucial. Only the government provides incentive policies for enterprises that can support the research and development of GH. Most of the practitioners also expressed considerable attention for the initial incremental cost. These practitioners are rational-economic people that pursue individuals' maximum economic benefits in the short term but neglect the social and environmental benefits in the GH life cycle. According to the realistic situation and past experiences, the lifetime of buildings in China is no longer than 30 years, which is considerably shorter than that in developed countries. Consequently, the convention that only less people are concerned with the benefits in the long run is formed. Therefore, high GH price will lead to a low WTP. Similar conclusions were reported in other papers [27,58].

Table 9. Variables in equation.

\begin{tabular}{ccccccc}
\hline Variable & B & S.E. & Wald & df & sig & Exp (B) \\
\hline Environmental concern & 0.463 & 0.225 & 4.222 & 1 & 0.04 & 1.589 \\
GH price & -0.558 & 0.212 & 6.915 & 1 & 0.009 & 0.573 \\
GH comfort & 0.409 & 0.178 & 5.285 & 1 & 0.022 & 1.505 \\
Governmental incentive policies & 0.422 & 0.215 & 3.856 & 1 & 0.05 & 1.525 \\
Neighbors' / friends' assessment & 0.644 & 0.199 & 10.489 & 1 & 0.001 & 1.903 \\
Mature GH market & 0.006 & 0.261 & 0.001 & 1 & 0.982 & 1.006 \\
Degree of GH popularity & 0.103 & 0.204 & 0.258 & 1 & 0.612 & 1.109 \\
GH publicity from developers & -0.084 & 0.273 & 0.094 & 1 & 0.759 & 0.92 \\
GH affordability & -0.284 & 0.217 & 1.709 & 1 & 0.191 & 0.753 \\
Constant & -4.089 & 0.995 & 16.894 & 1 & 0.000 & 0.017 \\
\hline
\end{tabular}

H3 was supported, with B3 $=0.409$ and EXP $($ B3 $)>1$. GH comfort was the first weakest factor to influence the WTP for GH. An intention to improve the quality of life can lead to high WTP for GH. In accordance with Maslow's hierarchy of needs in GB [59], the living space should follow the requirement of physiological needs, safety needs, society needs, esteem, and self-actualization. When the most basic living requirement is satisfied, practitioners will likely pursue improvements in their living environment. However, only the high-income groups will upgrade their living conditions and pursue the GH comfort due to the annually increasing house prices in China. These groups may be insensitive to the high GH price, and they can pay for GH without hesitation.

\subsubsection{Practitioners' Subjective Norm}

$\mathrm{H} 4$ was also supported, with B4 $=0.422$ and EXP (B4) $>1$. Government incentive policies were identified as the second weakest factor to influence the WTP for GH. Government incentive policies, especially in the aspect of economics, will generate high WTP for GH. Given the market externality and asymmetric information in the GH market, a market failure will lead to a low WTP for GH without interference from the government. Hence, the government should supply incentive policies to consumers at the beginning of the GH market. These incentives can be in the form of direct grants, subsidies, tax deductions, and exemptions. This result was also observed in research that indicated that market-based policy instruments are established to encourage proenvironmental behavior through economic incentive or price signals [11]. However, the consumers who buy two- and three-star-certified GBs in China can only attain the subsidy of 45 and 80 Chinese Yuan per square meter, respectively [60]. The subsidy amount is considerably limited relative to the high GH price, which results in the difficulty in motivating their purchasing intention. Therefore, the government should increase the incentive strength from fiscal support to attract the practitioners to pay for GH. Nevertheless, relying only on fiscal support is considerably difficult to sustain in the long term. A practical approach is the introduction of a market mechanism from private capital, such as a public-private partnership or energy performance management. 
H5 was supported, with B5 $=0.644$ and EXP5 $>1$. Results showed that the neighbors' $/$ friends' $^{\prime}$ assessment was the strongest factor to influence the WTP for GH, which conformed to the relational culture in China. Herd mentality is a basic psychology that most individuals tend to accept the opinions of most individuals around them and imitate them, which can interpret the result. The practitioners' own perception, judgment, knowledge, and behavior tend to conform to public opinion or the majority of individuals' behavior, especially from neighbors or friends, due to bandwagon effects. With the large number of individuals supporting the purchase of $\mathrm{GH}$, the $\mathrm{GH}$ will be highly selected. Similar conclusions were found in other studies [58,61,62].

However, a mature GH market (H6) was unsupported. This variable exerted no significant influence on the WTP, with the "sig" values higher than 0.05. The directions of hypotheses H6 are consistent with the assumed directions. The result may be due to the observation that GH is characterized with a large amount of expense and one-time consumerism. Generally, GH may hardly cost the whole family's income or require a long-time bank loan. With the tradeoff among the cost of GH and work, life convenience, educational resource, and GH comfort, practitioners will be particularly prudent to make the most of ideal decisions, regardless of the maturity of the GH market. Additionally, although GH has been certified in the design stage and evaluated only by the shop drawings, a considerably limited number of GH certifications were obtained in the operational stage and assessed by the actual performance. According to a report from the Ministry of Housing and Urban-Rural in China, 4071 projects attained the label of GB until the end of December in 2015, and only 212 were certified in the operational stage [63]. Therefore, the mature market in the GH life cycle has yet to be formed.

\subsubsection{Practitioners' Perceived Behavioral Control}

The degree of GH popularity (H7) and the GH publicity from developers (H8) were also unsupported. These factors exerted no significant influences on WTP, with the "sig" values higher than 0.05. One possible reason is that the sample number is small and insufficient. The sample size should be large enough to obtain a strong result supported by statistical analysis.

The degree of GH popularity (H7) also exerted no significant influence on the WTP for GBs, which may be due to the incomplete information about GH throughout China. Practitioners only know the GH in a local region. The degree of GH popularity is largely different between developed and underdeveloped regions. In general, the low GH popularity in underdeveloped regions exerts no significant influence on the WTP for GH. In developed regions with high GH popularity, such as Jinan City, the result may be different. On the basis of the consumer heterogeneity theory, the difference may be attributed to that different practitioners report different economic conditions and GH preferences; some of them are probably unmotivated by the degree of GH popularity.

GH publicity from developers (H8) is inconsistent with the survey results, but it contradicts the results of other studies for consumers' WTP for GB [64]. The difference can be due to that practitioners are more familiar with advertisements from developers than those of ordinary consumers in China. They concluded that the GH publicity from developers is related to the low level of trust from past working experiences. False actions, including exaggerated and misleading advertising, may be observed in the process of sales, which can lead to substantial differences between publicity and reality. Therefore, practitioners may ignore the GH publicity from developers, which is in accordance with the study result.

The GH affordability (H9) exerted no significant influences on WTP. This factor is commonly regarded as a significant factor in other types of green consumerism. Although construction practitioners, either in real estate, design, or construction companies or the material or equipment suppliers, are familiar with the GH, the transaction costs incurred in the GH market are considerably larger, which prevents GH promotion. Transaction costs are also the main obstacles in other studies $[9,55]$. The development of GH in China remains in the nascent stage due to the immature GH 
market mechanism. Thus, construction practitioners with strong GH affordability are probably not willing to pay for $\mathrm{GH}$.

The respondents were mainly selected in Jinan City, which is a frontrunner in the development of GB in China. At the end of 2017, Jinan ranked 4th in the number of GBs at the province level in China; subsequently, this city was awarded with 214 GBs and 18 LEED projects (http:/ / www.gbmap.org/). The present findings can be extended to other cities, which can provide valuable references to the government and developers. With extensive propaganda from the country, province, city, and native community levels, many general consumers will obtain sufficient knowledge about GH and an improved analysis of its features. The present results can also be adopted to other consumer groups in the future.

\section{Conclusions}

On the basis of the context of rapid urbanization in China, GH is fast becoming mainstream in the construction industry due to its positive influences on economic transition, environmental protection, and social sustainability. GH has attracted the increasing attention of scholars and practitioners from developed and developing countries. This paper focuses on the practitioners' WTP for GH in the construction industry. The attitudes and decisions of these practitioners will provide a strong demonstration effect on general consumers. According to the questionnaire survey, a binary regression analysis was adopted. Results indicated that five factors exerted significant influences on WTP. Four of these factors, namely, strong environmental awareness, GH comfort, governmental incentive policy, and neighbors' / friends' assessment, presented positive and significant influences on WTP. On the contrary, GH price exerted negative and significant influences. The remaining four factors with no significant influences were mature GH market, degree of GH popularity, GH publicity from developers, and GH cognition.

Therefore, to improve the practitioners' WTP for GH and achieve the large-scale development of GH, the government should offer additional GH publicity to the consumers by public media or community education. Consequently, many consumers will learn about the advantages of GH and provide a positive assessment to their neighbors or friends. Furthermore, the government should provide sufficient economic incentive and fiscal support to practitioners, as well as introduce the market mechanism from private capital. The government should also motivate developers to apply for GH certification in the operational stage, which provides convenience to consumers in distinguishing authentic green products and eliminating concerns about the benefits of GH. However, this study limits the respondents to construction practitioners, which may not indicate the real GH market. In future research, the sample size should be larger and a diverse demographic population should be represented, such as teachers, students and old ones, who should be considered in the questionnaire survey. In addition, other methods, such as expert interviews and grounded theory, should be introduced to identify critical factors and further enrich the range of factors. Furthermore, key factors based on consumption psychology theory, for instance Veblen's paradox, can be considered to broaden the scope of green building research.

Author Contributions: L.Z. wrote the paper; W.D. performed the survey, L.Z. and H.X. designe the questionnaire and analyzed the data. Z.W. contributed to detailed revision of the paper. L.C. conducted supervision of the manuscript conceptualization.

Acknowledgments: This work was financially supported by the National Social Science Foundation of China (Grant number 14BJY060), Shandong Province Social Science Foundation of China (Grant number 17CGLJ12), Jinan Social Science Foundation of China (Grant number JNSK18DS12), Shandong Province Department of Education (J17RB092), Shandong Province Soft Science (2017RKB01068) and the National Science Foundation of China (Grant number 71403150). The authors would also like to thank all those who contributed to the interviews and reviewed the manuscript.

Conflicts of Interest: The authors declare no conflict of interest. 


\section{References}

1. Zhang, Y.R.; Wang, J.J.; Hu, F.F.; Wang, Y.F. Comparison of evaluation standards for green building in China, Britain, United States. Renew. Sustain. Energy Rev. 2017, 68, 262-271. [CrossRef]

2. Zuo, J.; Zhao, Z.Y. Green building research-current status and future agenda: A review. Renew. Sustain. Energy Rev. 2014, 30, 271-281. [CrossRef]

3. Miller, N.; Spivey, J.; Florance, A. Measuring the Green Premium for Office Buildings. ICSC Res. Rev. 2008, 15, 35-39.

4. Kok, N.; Miller, N.G.; Morris, P. The Economics of Green Retrofits. J. Sustain. Real Estate 2012, 4, 4-22.

5. Miller, N.; Pogue, D.; Gough, Q.; Davis, S. Green Buildings and Productivity. J. Sustain. Real Estate 2009, 1, 65-89.

6. Zeng, H. Research on Influential Factors of Developing Green Buildings in Real Estate Enterprises; Zhe Jiang University: Zhejiang, China, 2013. (In Chinese)

7. Huang, D. Evolutionary game analysis of green building demand side based on profit risk. China Civ. Eng. J. 2017, 2, 110-118.

8. Zhang, L.; $\mathrm{Wu}, \mathrm{J} . ; \mathrm{Liu}, \mathrm{H}$. Turning green into gold: A review on the economics of green buildings. J. Clean. Prod. 2018, 172, 2234-2245. [CrossRef]

9. Qian, Q.K.; Chan, E.H.W.; Khalid, A. Challenges in Delivering Green Building Projects: Unearthing the Transaction Costs (TCs). Sustainability 2015, 7, 3615-3636. [CrossRef]

10. Gu, L.; Zhang, J. Research on the Status and Trends of Developers' Developing Green Building in China. Chin. Energy Source 2014, 36, 35-38.

11. Yau, Y. Eco-labels and Willingness-to-pay: A Hong Kong Study. Smart Sustain. Built Environ. 2012, 1, $277-290$. [CrossRef]

12. Robinson, S.; Simons, R.; Lee, E.; Kern, A. Demand for Green Buildings: Office Tenants' Stated Willingness-to-Pay for Green Features. J. Real Estate Res. 2016, 38, 423-452.

13. Attaran, S.; Celik, B.G. Students' environmental responsibility and their willingness to pay for green buildings. Int. J. Sustain. High. Educ. 2015, 16, 327-340. [CrossRef]

14. Hu, H.; Geertman, S.; Hooimeijer, P. The willingness to pay for green apartments: The case of Nanjing, China. Urban Stud. 2014, 51, 3459-3478. [CrossRef]

15. Zalejska-Jonsson, A. Stated WTP and rational WTP: Willingness to pay for green apartments in Sweden. Sustain. Cities Soc. 2014, 13, 46-56. [CrossRef]

16. Zhang, L.; Wang, Y.; Zheng, S. How important is the information for green residential market-The empirical study of information sufficiency influencing on the consumers' willingness to pay. Chin. Real Estate 2015, 12, 45-51.

17. Zhang, L.; Cai, S.; Zheng, S.; Lin, R. Who are more willing to buy green residential—Characteristics of Residents' willingness to pay for green housing. Chin. Real Estate 2015, 18, 23-31.

18. Huang, H. Study on the Influence Factors of Willingness to Pay for Green House in Lanzhou City; Lanzhou Jiaotong University: Lanzhou, China, 2014. (In Chinese)

19. Zhang, L.; Chen, L.; Wu, Z.; Zhang, S.; Song, H. Investigating Young Consumers' Purchasing Intention of Green Housing in China. Sustainability 2018, 10, 1044. [CrossRef]

20. Yau, Y.; Shuk, M.C.; Lau, W.K. Economising subsidies for green housing features: A stated preference approach. Urbani Izziv 2014, 25, 107-118. [CrossRef]

21. Chan, E.H.W.; Qian, Q.K.; Lam, P.T.I. The market for green building in developed Asian cities-The perspectives of building designers. Energy Policy 2009, 37, 3061-3070. [CrossRef]

22. Heinzle, S.L.; Boey Ying Yip, A.; Low Yu Xing, M. The Influence of Green Building Certification Schemes on Real Estate Investor Behaviour: Evidence from Singapore. Urban Stud. 2013, 50, 1970-1987. [CrossRef]

23. Zhang, L.; Sun, C.; Liu, H.; Zheng, S. The role of public information in increasing homebuyers' willingness-to-pay for green housing: Evidence from Beijing. Ecol. Econ. 2016, 129, 40-49. [CrossRef]

24. Nguyen, H.-T.; Skitmore, M.; Gray, M.; Zhang, X.; Olanipekun, A.O. Will green building development take off? An exploratory study of barriers to green building in Vietnam. Resour. Conserv. Recycl. 2017, 127, 8-20. [CrossRef]

25. Davis, L.W.; Metcalf, G.E. Does Better Information Lead to Better Choices? Evidence from Energy-Efficiency Labels. Discuss. Pap. 2015, 3, 589-625. 
26. Kotchen, M.J.; Boyle, K.J.; Leiserowitz, A.A. Willingness-to-pay and policy-instrument choice for climatechange policy in the United States. Energy Policy 2013, 55, 617-625. [CrossRef]

27. Grosskopf, K.R.; Kibert, C.J. Market-Based Incentives for Green Building Alternatives. J. Green Build. 2006, 1 , 141-147. [CrossRef]

28. Yazdanpanah, M.; Forouzani, M. Application of the Theory of Planned Behaviour to predict Iranian students' intention to purchase organic food. J. Clean. Prod. 2015, 107, 342-352. [CrossRef]

29. Yadav, R.; Pathak, G.S. Young consumers' intention towards buying green products in a developing nation: Extending the theory of planned behavior. J. Clean. Prod. 2016, 135, 732-739. [CrossRef]

30. Tan, C.-S.; Ooi, H.-Y.; Goh, Y.-N. A moral extension of the theory of planned behavior to predict consumers' purchase intention for energy-efficient household appliances in Malaysia. Energy Policy 2017, 107, 459-471. [CrossRef]

31. Chan, R.Y.K.; Lau, L.B.Y. Explaining Green Purchasing Behavior. J. Int. Consum. Mark. 2002, 14, 9-40. [CrossRef]

32. Robichaud, L.B.; Anantatmula, V.S. Greening Project Management Practices for Sustainable Construction. J. Manag. Eng. 2011, 27, 48-57. [CrossRef]

33. Wu, Z.; Yu, A.T.; Shen, L. Investigating the determinants of contractor's construction and demolition waste management behavior in Mainland China. Waste Manag. 2017, 60, 290-300. [CrossRef] [PubMed]

34. Maichum, K.; Parichatnon, S.; Peng, K.C. Application of the Extended Theory of Planned Behavior Model to Investigate Purchase Intention of Green Products among Thai Consumers. Sustainability 2016, 8, 1077. [CrossRef]

35. Ajzen, I. Perceived Behavioral Control, Self-Efficacy, Locus of Control, and the Theory of Planned Behavior. J. Appl. Soc. Psychol. 2002, 32, 665-683. [CrossRef]

36. Kumar, B.; Manrai, A.K.; Manrai, L.A. Purchasing behaviour for environmentally sustainable products: A conceptual framework and empirical study. J. Retail. Consum. Serv. 2017, 34, 1-9. [CrossRef]

37. Moons, I.; De Pelsmacker, P. An Extended Decomposed Theory of Planned Behaviour to Predict the Usage Intention of the Electric Car: A Multi-Group Comparison. Sustainability 2015, 7, 6212-6245. [CrossRef]

38. Han, H.; Hsu, L.-T.; Sheu, C. Application of the Theory of Planned Behavior to green hotel choice: Testing the effect of environmental friendly activities. Tour. Manag. 2010, 31, 325-334. [CrossRef]

39. Shan, K.; Wu; Man, T.Y. Applying the extended theory of planned behavior to predict the intention of visiting a green hotel. Afr. J. Bus. Manag. 2011, 5, 7579-7587. [CrossRef]

40. Wang, Z.; Zhang, B.; Li, G. Determinants of energy-saving behavioral intention among residents in Beijing: Extending the theory of planned behavior. Renew. Sustain. Energy Rev. 2014, 6, 1-17. [CrossRef]

41. Macovei, O.-I. Applying the Theory of Planned Behavior in Predicting Pro-environmental Behaviour: The Case of Energy Conservation. Int. J. Approx. Reason. 2015, 54, 701-716.

42. Bamberg, S. How does environmental concern influence specific environmentally related behaviors? A new answer to an old question. J. Environ. Psychol. 2003, 23, 21-32. [CrossRef]

43. Tan, M.Q.B.; Tan, R.B.H.; Khoo, H.H. Prospects of carbon labelling-A life cycle point of view. J. Clean. Prod. 2014, 72, 76-88. [CrossRef]

44. Li, Q.; Long, R.; Chen, H. Empirical study of the willingness of consumers to purchase low-carbon products by considering carbon labels: A case study. J. Clean. Prod. 2017, 161, 1237-1250. [CrossRef]

45. Chau, C.K.; Tse, M.S.; Chung, K.Y. A choice experiment to estimate the effect of green experience on preferences and willingness-to-pay for green building attributes. Build. Environ. 2010, 45, 2553-2561. [CrossRef]

46. Gerpott, T.J.; Paukert, M. Determinants of willingness to pay for smart meters: An empirical analysis of household customers in Germany. Energy Policy 2013, 61, 483-495. [CrossRef]

47. Dwaikat, L.N.; Ali, K.N. Green buildings cost premium: A review of empirical evidence. Energy Build. 2016, 110, 396-403. [CrossRef]

48. Hwang, B.G.; Tan, J.S. Green building project management: Obstacles and solutions for sustainable development. Sustain. Dev. 2012, 20, 335-349. [CrossRef]

49. Issa, M.H.; Rankin, J.H.; Christian, A.J. Canadian practitioners' perception of research work investigating the cost premiums, long-term costs and health and productivity benefits of green buildings. Build. Environ. 2010, 45, 1698-1711. [CrossRef] 
50. Kim, J.L.; Greene, M.; Kim, S. Cost comparative analysis of a new green buildingcode for residential project development. Constr. Eng. Manag. 2014, 140, 1-10.

51. Liang, H.-H.; Chen, C.-P.; Hwang, R.-L.; Shih, W.-M.; Lo, S.-C.; Liao, H.-Y. Satisfaction of occupants toward indoor environment quality of certified green office buildings in Taiwan. Build. Environ. 2014, 72, 232-242. [CrossRef]

52. Marchand, R.D.; Koh, S.C.L.; Morris, J.C. Delivering energy efficiency and carbon reduction schemes in England: Lessons from Green Deal Pioneer Places. Energy Policy 2015, 84, 96-106. [CrossRef]

53. Li, X.; Li, H.; Wang, X. Farmers' willingness to convert traditional houses to solar houses in rural areas: A survey of 465 households in Chongqing, China. Energy Policy 2013, 63, 882-886. [CrossRef]

54. Laufer, D.; Schäfer, M. The implementation of Solar Home Systems as a poverty reduction strategy-A case study in Sri Lanka. Energy Sustain. Dev. 2011, 15, 330-336. [CrossRef]

55. Qian, Q.K.; Chan, E.H.W.; Visscher, H.; Lehmann, S. Modeling the green building (GB) investment decisions of developers and end-users with transaction costs (TCs) considerations. J. Clean. Prod. 2015, 109, 315-325. [CrossRef]

56. Gong, R. Study on the Promotion of Green Building in Chognqing Based on the Consumer Perspective; Chognqing University: Chognqing, China, 2016. (In Chinese)

57. Kumar, B. Theory of Planned Behaviour Approach to Understand the Purchasing Behaviour for Environmentally Sustainable Products; IIMA Working Papers WP2012-12-08; Indian Institute of Management Ahmedabad, Research and Publication Department: Ahmedabad, India, 2012.

58. Worzala, E.B.S. Barriers and drivers to green buildings in Australia and New Zealand. J. Prop. Investig. Financ. 2011, 29, 494-509.

59. Zhao, D.X.; He, B.J.; Johnson, C.; Mou, B. Social problems of green buildings: From the humanistic needs to social acceptance. Renew. Sustain. Energy Rev. 2015, 51, 1594-1609. [CrossRef]

60. Paulson Institute. Available online: http://www.paulsoninstitute.org.cn/index.php/economics-environment/ climate-sustainable-urbanization/research/ (accessed on 15 May 2018).

61. Allouhi, A.; El Fouih, Y.; Kousksou, T.; Jamil, A.; Zeraouli, Y.; Mourad, Y. Energy consumption and efficiency in buildings: Current status and future trends. J. Clean. Prod. 2015, 109, 118-130. [CrossRef]

62. Gan, X.; Zuo, J.; Ye, K.; Skitmore, M.; Xiong, B. Why sustainable construction? Why not? An owner's perspective. Habitat Int. 2015, 47, 61-68. [CrossRef]

63. Song, L.; Zhang, C.; Li, H.J. Statistical report on assessment label of green buildings in China in 2015. Constr. Technol. 2016, 10, 12-15.

64. Hu, W.L. The Research on Consumers' Willingness to Pay and Motivation for Green Building; Changsha University of Science and Technology: Changsha, China, 2014. (In Chinese) 